\title{
The Effectiveness of Higher Order Thinking Skill (HOTS) Based Learning Model Through Using E-Learning and Interactive Multimedia on ICT Learning
}

\author{
R. Mursid \\ Department of Educational Technology \\ Faculty of Postgraduate Program \\ State University of Medan \\ Medan, Indonesia \\ Corresponding email: mursid.tp@gmail.com
}

\begin{abstract}
This study aims to determine the differences in the effectiveness of the use of HOTS-based learning model using elearning and HOTS-based learning model by using interactive multimedia in ICT learning. This research method using quasi experiment with research population is all student of study program of education technology. The sampling technique using simple random sampling. The research instrument is activity observation sheet and test for achievement of student learning result. Data analysis begins with descriptive analysis, and analyzed with one sample t-test test statistic at $5 \%$ significance level. The results showed that there is a significant difference between learning by using e-learning and learning by using interactive multimedia on ICT learning in HOTS-based education. The implementation of HOTS-based learning model using e-learning in ICT learning is more effective than HOTSbased learning model application using interactive multimedia and also on student activity and learning outcomes.
\end{abstract}

Keywords--component; learning model; HOTS; e-learning; interactive multimedia; ICT.

\section{INTRODUCTION}

Information and Communication Technology (ICT) is a technology used to store, generate, manage, and disseminate information. From various definitions of ICT it can be concluded that ICT is not just a communication tool, computer or just some media only, ICT has a broader meaning than that. According to Victoria Tinio in his book ICT in Education [1]. ICT is defined as the goal to communicate complemented by its supporting tools to create, disseminate, store information and manage it.

ICT is a technology that makes information as a processed commodity [2]. Implementation of education in the form of learning in the college is loaded with information that must be processed by the learners so that it becomes something meaningful. Viewed from the learner how much, how important and how interesting the information is so it can be assimilated into something meaningful. Viewed from the teacher how the information is presented or delivered so that the learner can easily accept it. This is where information technology will play a very important role how to process teaching materials as a form of information so interesting, easy to accept and every student has the same opportunity to get it.

Utilization of information technology aims to; (1) improve competitive positioning; (2) increase brand image; (3) improving the quality of learning and teaching; (4) increasing student satisfaction; (5) increase revenue; (6) expanding the student base; (7) improvement of service quality; (8) reduce operating costs; and (9) developing new products and services [3]. Therefore, it is not surprising that today many universities in Indonesia are competing to invest in the field of information technology to win the increasingly fierce competition.

The progress of ICT has also enabled the utilization of various types / kinds of media simultaneously in the form of multimedia learning. The use of interactive multimedia that includes audio-visual components (voice and display) for the delivery of learning materials can attract students to learn. Interactive multimedia can also provide opportunities for students to conduct quasi-experimental and exploratory experiments so as to provide a learning experience rather than merely hearing the lecturer's description / explanation.

To improve the quality of education, especially the quality of learning through the utilization of ICT. In addition to its function as a tool for solving human problems, ICT can also be used to support the learning process that is believed to be [4]: (1) improving the quality of learning; (2) expanding access to education and learning; (3) reduce education costs; (4) answering the necessity of participating in ICT; and (5) develop the ICT skills (ICT skills) that students need when working and in their later lives. The ICT utilization strategy in learning includes: (1) as a learning tool or media, (2) as a learning facility, (3) as a learning resource, and (4) as a means of promoting professionalism.

Associated with the integration of ICT in learning computer turns can be used as a tool to involve students in thinking [5]. There are three steps how the use of ICT can enrich teaching and learning that stimulates thinking skills. The three steps are: 
(1) supporting the dynamics of information delivery; (2) act as a lecturer to encourage learning but at the same time apply as a learning resource when students discuss and explore ideas; and (3) the existence of a computer network makes students can create directly with other students without being limited space and time. In particular giving clues in integrating ICT in learning is facilitating student learning. Through the learning process students are expected to: (1) apply the principles of pedagogy critically; (2) developing and facilitating learning activities; (3) analyze and evaluate the subject matter with; (4) using various communication tools and multimendia tools (email, web and virtual labs) in the learning process; (5) research activities, helping problem solving subject matter; (6) develop professionalism in learning; and (7) integrating curricula that can deliver students in ICT-based learning [6].

According to Rogers [7] There are fundamental aspects of ICT contributions in the learning process: (1) concepts: constructive models are well suited to describe the study of concepts. Concept development is very dominant and influences in learning; (2) skills and application: understanding the variables and testing them, repeating a measurement and interpreting data using a particular software will add to the enrichment in learning; (3) knowledge: behaviorist model: appropriate in learning in the form of broad material structut; and (4) in accordance with the objectives: to develop learning activities using ICT included in the learning objectives [7].

The progress of ICT has also enabled the utilization of various types / kinds of media simultaneously in the form of multimedia learning. The use of interactive multimedia that includes audio-visual components (voice and display) for the delivery of learning materials can attract students to learn. Interactive multimedia can also provide opportunities for students to conduct quasi-experimental and exploratory experiments so as to provide a learning experience rather than merely hearing the lecturer's description / explanation. ICT can improve the motivation, skills, structure of thinking communicates electronically and more actively in learning. The actual learning process change that is theoretically is giving the participants the opportunity to learn to act actively, constructively, dialogically, constructively contextual and reflective.

These attitudes and actions can be interpreted as follows: (1) active; enables students to be actively involved in the learning process as well as interesting and meaningful; (2) constructive; enables students to incorporate new ideas into previously possessed knowledge in order to understand the meaning or desire of knowledge and doubt that has been in their thinking; (3) collaborative; enables students to study in groups or learn in a community so that participants learn to work together, share ideas, suggestions or experiences, advise each other and provide input to fellow members of their group and community; (4) enthusiastic; enables students to play an active role and full of enthusiasm and always strive to achieve the desired goals in learning; (5) dialogical; enables synergistic learning and is a social and dialogical process whereby students benefit from communication processes built both within and outside the school. (6) contextual; enables learning situations to be directed toward real-world learning through "problem-based and case-study approaches; (6) Reflective; enables students to be conscious of what they have learned and reflect on what they have learned so that this action is a the learning process itself [8].

E-Learning is an effective learning process that is generated by combining digital content delivery consisting of support and services in learning [9]. Digital concepts according to Waller is hinted not only the internet, but all electronic devices today are using a digital system. Along with that the development of computer use in learning has encouraged the arrangement of computer equipment as learning aids called computer managed learning (CML). CML through the web is very efficient for delivering lecture material and gives students the opportunity to learn from anywhere 'and anytime without being limited to the place and time of study [10]. The Internet is not only a means of information and communication, but it is a very important learning resource because the current learning materials are widely available in the virtual world (Web). Using the internet in learning is very difficult for students and lecturers because it can access full and clear scientific information. Web-based learning innovation in science learning has been successful [11].

Multimedia must consider three things, namely: (1) method, ie techniques and procedures used in learning (cooperation, gaming, presentation, or discussion); (2) media, ie media used in learning to attract student interest (video, text, images, and animation); and (3) material, that is learning content covering: motivation, orientation, information, application, and evaluation [12]. In line with that, learning multimedia that berkualtas must meet the criteria, namely: (1) the quality of content and objectives, which include: accuracy, importance, completeness, balance, attractiveness, reasonableness, and conformity with the student situation; (2) instructional qualities that include: providing learning opportunities, providing assistance to learn, motivating qualities, instructional flexibility, relationships with other teaching programs, test quality and assessment, can have an impact on students, can impact on lecturers and their learning; and (3) technical quality, including: legibility, ease of use, display quality / impressions, quality of student response handling, program management quality, and documentation quality [13].

There are three kinds of interactive multimedia design that is: (1) design documentation, (2) navigation design, and (3) graphic design [14]. While the multimedia development procedure includes six steps, namely: (1) analyzing the needs and characteristic of students; (2) to formulate instructional objectives with operational and distinctive; (3) to formulate detailed items of material that support the achievement of objectives; (4) developing a means of measuring success; (5) making of media; and (6) conduct tests and revisions [15].

The use of multimedia in learning found evidence that presenting a verbal explanation of how a system works does not guarantee a person can understand the explanation [16]. Research has also found evidence that an effective way to help scientific information be more easily understood is through the visualization of information in a multimedia format. Rosch further defines multimedia as a combination of computers and videos. Multimedia definitions that depart from the messaging design aspect are used to describe multimedia according to an 
instructional review in Merrill [17], namely: "the capability to present video, audio, and animation, as well as computer graphics and text, all on the same computer monitor at the same time."

Learning multimedia refers to presentations made by prioritizing visual elements (related to animated, video, and color) and verbal images (related to sounds such as language elements such as narration, text, and labels). According the latest theories about information processing, states that new information must be processed by visual and / or auditory memory. Knowledge processed in working memory is stored in long-term memory in the form of hierarchically arranged schemes [18].

Thus, research needs to be done about the effectiveness of learning by using HOTS-based learning model through the use of e-learning and interactive multimedia on ICT learning.

\section{METHOD}

This research is a quasi experimental research (quasi experiment), with pretest posttest non-equivalent group design design. This research is conducted in Education Technology study program in semester 2 . The population of this research is the second semester students of Education Technology in Education Program of Academic Year 2016/2017 that is as much as two classes. Samples are taken at random. Next, randomly selected class A as a class / group given treatment by learning using HOTS-based learning model and class B as a class / group of learning without using HOTS-based learning model.

Variables in the study there are two kinds of independent variables and dependent variables. The free variable is learning using HOTS-based learning model and learning without using HOTS-based learning model.

Instruments used in this study are test and non-test instruments. Intrumen achievement test is a matter of multiple choice and essay given at the beginning of treatment (pretest) and end of treatment (posttest). The scores obtained are then converted into values ranging from 0 to 100 . The scores are then classified into competency-based criteria designated as guidelines for academic assessment. Completeness of learning competence is used to determine the percentage of the number of students who achieve the criteria mastery. Instrument nontes in the form of questionnaire e-learning ability by using likert scale.

The stages in this research include: preparation stage, implementation stage and final stage. Preparatory stage, namely: training, making learning materials, preparing the RPS, preparing the instrument, determine the execution time. The implementation stage includes: performing pretest, treatment, and posttest. The final phase includes: processing and analyzing experimental data, discussing, concluding and reporting research results. Data needed in this research is the ability of e-learning and interactive multimedia. Data collection techniques that will be used are the ability of e-learning and interactive multimedia, ICT achievement test, and observation.
The data analysis begins with descriptive analysis, and to describe the effectiveness of learning with HOTS-based learning model, the data is analyzed by one-sample t-test test at significance level of $5 \%$. The data described is the data obtained from the measurement on the research variables (dependent variable) that is the mastery of e-learning and interactive multimedia. The data is calculated the average value then interpreted into predetermined criteria.

\section{RESULTS}

Based on the results of the analysis of descriptive statistics in Table 1, it can be seen that the average posttest result of learning achievement in the learning group using HOTS-based learning model. Result of Pretest and Posttest of ICT Achievement.

TABLE I. PRETEST AND POSTTEST RESULTS ICT ABILITY

\begin{tabular}{|l|c|c|c|c|}
\hline & \multicolumn{2}{|c|}{$\begin{array}{c}\text { The group used the } \\
\text { HOTS Group-based } \\
\text { learning model }\end{array}$} & \multicolumn{2}{c|}{$\begin{array}{c}\text { The Group without using } \\
\text { HOTS-based learning } \\
\text { model }\end{array}$} \\
\hline & Pre & Post & Pre & Post \\
\hline Average & 28,57 & 71,25 & 26,18 & 73,82 \\
\hline SD & 5,15 & 7,85 & 5,63 & 7,64 \\
\hline Maximum & 38 & 97 & 44 & 75 \\
\hline Minimum & 23 & 57 & 19 & 48 \\
\hline Completeness & \multicolumn{2}{|c|}{$87,24 \%$} & \multicolumn{2}{|c|}{$12,76 \%$} \\
\hline
\end{tabular}

ICT learning achievement in both classes / groups and shows that the average of student achievement learning using HOTS-based learning model is much better than the average achievement of student learning without using HOTS-based learning model.

Based on Table I, students in the group without using HOTS-based learning model did not have as good percentage in the group using HOTS-based learning model. The percentage of group interest using HOTS-based learning model, on very high and high criteria, reached $87.24 \%$. Percentage of group interest without using HOTS-based learning model on very high and high criterion only reached $12,76 \%$. This means that students in groups using HOTS-based learning models are more interested in ICT learning than students in groups who do not use HOTS-based learning models in learning. This research data is then analyzed to know the effectiveness of each learning group then tested one sample $\mathrm{t}$ test using SPSS 16 for windows. Hypothesis testing using one sample t-test can be done if the assumption of normality is met. Based on the results of normality test using Kolmogorov Smirnov test, the results presented in Table II. 
TABLE II. DISTRIBUTION OF LEARNING SKILLS USING ELEARNING AND INTERACTIVE MULTIMEDIA

\begin{tabular}{|l|c|c|c|}
\hline \multirow{1}{*}{ Group } & Description & Pretest & Posttest \\
\cline { 2 - 4 } & & $\mathbf{\%}$ & $\mathbf{\%}$ \\
\hline \multirow{4}{*}{$\begin{array}{l}\text { Using HOTS-based } \\
\text { learning model. }\end{array}$} & Very High & 0 & 47,36 \\
\cline { 2 - 4 } & High & 0 & 42,44 \\
\cline { 2 - 4 } & Medium & 25,57 & 10,2 \\
\cline { 2 - 4 } & Low & 74,43 & 0 \\
\cline { 2 - 4 } & Very Low & 0 & 0 \\
\hline \multirow{4}{*}{$\begin{array}{l}\text { Not using HOTS- } \\
\text { based learning } \\
\text { model. }\end{array}$} & Very High & 0 & 7,47 \\
\cline { 2 - 4 } & High & 0 & 21,42 \\
\cline { 2 - 4 } & Medium & 92,71 & 71,11 \\
\cline { 2 - 4 } & Low & 7,29 & 0 \\
\cline { 2 - 4 } & Very Low & 0 & 0 \\
\hline
\end{tabular}

TABLE III. NORMALITY TEST RESULTS AFTER KOLMOGOROVSMIRNOV TEST TREATMENT

\begin{tabular}{|l|c|c|}
\hline \multicolumn{1}{|c|}{ Group } & Variables & Significance Value \\
\hline Using HOTS-based & e-Learning & 0,62 \\
\cline { 2 - 3 } learning model. & Interactive multimedia & 0,34 \\
\hline $\begin{array}{l}\text { Without using HOTS- } \\
\text { based learning model. }\end{array}$ & e-Learning & 0,65 \\
\cline { 2 - 3 } & Interactive multimedia & 0,76 \\
\hline
\end{tabular}

Normality Test Result after Kolmogorov-Smirnov Test Treatment showed that all signi fi can't values were greater than 0.05. This means that all data is normally distributed. Because the data is normally distributed, one sample t-test can be performed. Table IV presents the results of one sample ttest.

TABLE IV. LEARNING EFFECTIVENESS TEST RESULTS USING HOTS-BASED LEARNING MODEL AND LEARNING WITHOUT USING HOTS-BASED LEARNING MODEL.

\begin{tabular}{|l|c|c|c|}
\hline \multicolumn{1}{|c|}{ Group } & Variables & $\mathbf{T}_{\text {count }}$ & $\mathbf{T}_{\text {table }}$ \\
\hline \multirow{2}{*}{$\begin{array}{l}\text { Using HOTS-based learning } \\
\text { model. }\end{array}$} & e-Learning & 5,21 & \multirow{2}{*}{2,08} \\
\cline { 2 - 3 } $\begin{array}{l}\text { Without using HOTS-based } \\
\text { learning model. }\end{array}$ & Interactive multimedia & 5,35 & \\
\cline { 2 - 3 } & e-Learning & $-4,12$ & \\
\hline
\end{tabular}

It is concluded that, in learning using HOTS-based learning model, tcount value is bigger than ttable so it can be concluded that learning using HOTS-based learning model is effective in terms of mastery of e-learning and interactive multimedia on student ICT learning. In learning without using HOTS-based learning model tcount value is smaller than ttable so concluded learning without using HOTS-based learning model is not effective in terms of mastery of e-learning and interactive multimedia on student ICT learning.

Based on the test results show that the variance of both populations are the same. The results of normality test using Kolmogorov-Smirnov obtained signification value greater than 0.05 so it can be concluded normal distributed data. Due to the homogeneous and normally distributed scores data, the hypothesis test using independent samples t test can be done with the results presented in Table V.
TABLE V. HYPOTHESIS TEST RESULTS USING INDEPENDENT SAMPLE t-TEST

\begin{tabular}{|l|c|c|c|}
\hline \multicolumn{1}{|c|}{ Variables } & $\mathbf{t}_{\text {count }}$ & df & Sig. \\
\hline $\begin{array}{l}\text { Ability to use e-learning on learning result of } \\
\text { ICT }\end{array}$ & 7,45 & 24 & 0,00 \\
\hline $\begin{array}{l}\text { Ability to use interactive multimedia to } \\
\text { learning result of ICT }\end{array}$ & 6,47 & 24 & 0,00 \\
\hline
\end{tabular}

The result of comparison test of the effectiveness of learning with significance value less than 0,025 so that it can be concluded that learning using HOTS-based learning model is more effective than learning without using HOTS-based learning model in terms of ICT learning achievement on elearning mastery capability and interactive multimedia students.

\section{DISCUSSION}

The results of research on the use of HOTS-based learning model on ICT learning is closely related to the existence of elearning and interactive multimedia. But in the implementation of ICT learning there are some very important aspects as a reference in considering HOTS-based learning model. The aspect is the ability of students in the utilization of ICT to the maximum, in addition to facilities and infrastructure supporting ICT in accordance with the device specifications required for access speed in ICT performance. The pedagogical aspects and learning technologies are crucial and related to the ICT in question is the ICT conformity to constructivism learning theory, the supportive ability of student-centered learning, support for ICT skills development, HOTS-based learning, increased student learning motivation, student independence, and web suitability to student learning style, so ICT learning is very appropriate when using HOTS-based learning model.

Associated with the results of research on animation, according to Kulik and Kulik [19] e-learning based learning is known to support the creation of student learning environment that share experience, good social interaction, and collaboration in work. Some research states that e-learning is more effective in improving understanding in ICT learning because of the visualization in the form of animation and graphics and not just text only. De Jong, et al [20] stated that web-based multimedia designed for ICT learning can also improve the overall understanding of the material. Other studies show that Along with the need for ICT as an increasing source of learning from year to year, internet access also facilitates in adding repertoire of science, data, images, video and various other information. The Internet can also be utilized as a means to add, interpret and help learn and assist in the support of research activities effectively. However, in fact, integrating ICT in learning is a serious issue by science teachers in high schools, especially in RSBI Senior High School [21].

The ongoing ICT-based learning is broad-based, not just limited to tools, animation programs and information processing, but further than that. According to Galarneau (2006), for example how ICT-based learning will stimulate 21st century skills of collaboration skills, HOTS, and introduce ICT literacy in e-learning based learning. The design of ICT learning is expected to be able to hone HOTS pattern and to develop ICT skill (ICT literacy) in accordance with the policy 
of Presidential Instruction No. 6/2001, Keppres 20/2006, Kepmendiknas no. 50 / P / 2007, and UNESCO's mandate. These skills are part of the skills of the second century, which need to be provided to students to support the needs of the global workplace. patterns of interaction built by students in order to solve the problems presented in online interactive web assisted internet access'

The positive impact of ICT integration in learning is closely related to; (1) improvement of professionalism of lecturers in technology mastery; and (2) improve high-level thinking, improve learning quality where participants learn to think critically, improve skills, work together, build complex interactions between groups. According to (Becta, 2003), ICT can stimulate, motivate and encourage students in learning creatively in growing the learning climate. It can be proved that there is an increase in commitment in doing non-coercive tasks, so interested in improving learning when utilizing ICT.

\section{CONCLUSION}

Based on the results of data analysis and discussion can be concluded several things as follows. First, learning using HOTS-based learning model is effective in terms of ICT learning achievement in the use of e-learning and interactive m.ultimedia students. Second, learning without using HOTSbased learning model is not effective in terms of ICT learning achievement in the use of e-learning and interactive multimedia students. Third, there are differences in the effectiveness of learning using HOTS-based learning model and learning without using HOTS-based learning model in terms of ICT learning achievement in the use of e-learning and interactive multimedia students. Fourth, learning using HOTS-based learning model is more effective than learning without using HOTS-based learning model in terms of ICT learning achievement in the use of e-learning and interactive multimedia students.

\section{REFERENCE}

[1] L. Victoria, Tinio., ICT in Education. United Nations Development Programme, 2002

[2] B. Rahardjo, Implikasi Teknologi Informasi dan Internet terhadap Pendidikan, Bisnis dan Pemerintahan, PPAUME, ITB, 2000.

[3] M., Alavi, and R.B. Gallupe, Using Information Technology in Learning: Case Studies in Business and Management Education Programs. Academy of Management Learning and Education, 2003, 2(2), pp. 139-153.

[4] E. Krisnadi, Rancangan Materi Pembelajaran Berbasis ICT. disajikan dalam Workshop Pengembangan Materi Pembelajaran Berbasis ICT di FMIPA UNY pada tanggal 6 Agustus 2009.

[5] D. Jonassen, Thinking Technology: context is everything. Educational Technology. 1991, 31(6), pp. 35-37.

[6] O.G. Onwu, Chemistry, Integrated Learning with ICT in Chemistry, African Virtual UniversitY, 2009.

[7] L. Rogers, Integrated ICT into Science Education and The Future, Integrated Learning with 1CT, Springer, Germany, 2010.

[8] U.W. Chairuman, Rencana Pembelajaran yang Mengintegrasikan TIK dalam Pembelajaran, Pusat TIK Departemen Pendidikan Nasional Republik Indonesia, 2008.

[9] Waller, Vaughan and Wilson, Jim. A Definition for E-Learning" in Newsletter of Open and Distance Learning Quality Control. October 2001. (sumber dari internet: 11 September 2017 http://www.odlqc.org.uk/odlqc/n19-e.html).
[10] I. Forsyth, A. Jolliffe, and D. Stevens, Practical Strategies For Teachers, Lecturers and Trainers, Delivering Vol 3, Crest Publishing House, New Delhi, 2004.

[11] M.C. Cann, and T.A. Dickneider, Infusing The Chemistry Curriculum With Green Chemistry Using Real World. Examples, Web Modules, And Atom Economy In Organic Chemistry Course, Journal of Chemical Education 81: 977980, 2004

[12] T.J. Newby, S. Donald, L. James, D. James, Russell, and T.L. Anne, Instructional Technology for Teaching and Learning. New Jersey: Prentice-Hall Inc, 2000.

[13] A. Arsyad, Media Pembelajaran. Jakarta: Rajawali Pers, 2009.

[14] R. Phillips, R. The Developer's Handbook to Interactive Multimedia: A Practical Guide for Educational Applications. London: Kogan Page, 1997.

[15] A.S. Sadiman, R. Raharjo, H. Anung, dan Rahardjito. Media Pendidikan: Pengertian, Pengembangan dan Pemanfaatannya. Jakarta: Rajawali Pers, 2009.

[16] R.E. Mayer, and R.B. Anderson, Animations Need Narration: An experimental Test of a Dual Coding Hypothesis. Journal of Educational P sy chology. 1991. 83 (4) : 484- 490.

[17] M.D. Merrill, Computer-based design for computer-aided instruction. Dalam Tjeerd Plomp \&Donald P. Eli (Eds.), International Encyclopedia of Educational Technology, SecondEdition. Cambridge, MA: Cambridge University Press. 1996.

[18] P. Deubel, An investigation of behavioral and cognitive approaches to instructional multimedia design, Journal of Educational Multimedia and Hypermedia, 12(1), 2003, pp. 63-90.

[19] C. Kulik and J. Kulik J . In: Baker EL e O'Neill HF (eds) Technology assessment in Education and Training' New Jersey' Hillsdale: Lea Publishers, 1994.

[20] T. De Jong, and A. Van der Hulst, The Effectiveness of Computer Based Learning. journal of computer Assisted Learning , 2002, 1(18): 219-231.

[21] H.M, Sutrisno, Menata dan Mengembangkan RSBI (Studi Analisis RSBI) di Provinsi lambi, Hibah Stranas, 2009. 
